\title{
African Journal of Education and Practice
}

\section{(AJEP)}

THE EFFECTS OF CHRISTIAN RELIGIOUS STUDIES LITERACY ON ACADEMIC PERFORMANCE AND ACHIEVEMENT OF SECONDARY STUDENTS ON THEIR ACADEMIC ACHIEVEMENT: A CASE STUDY OF SECONDARY SCHOOL 1 STUDENTS IN QUAAN-PAN LOCAL GOVERNMENT IN PLATEAU STATE OF NIGERIA

DR. YOHANNA SATI KESMEN (PH.D.) and PETER AYUBA MELLEMUT 


\title{
The Effects of Christian Religious Studies Literacy on Academic Performance and Achievement of Secondary Students on their Academic Achievement: A Case Study of Secondary School 1 Students in Quaan-Pan Local Government in Plateau State of Nigeria
}

\author{
Dr. Yohanna Sati Kesmen (Ph.D.) \\ Department of Christian Religious Education, School of Arts/Social Sciences, Federal \\ College of Education, Pankshin, Plateau State of Nigeria. \\ yohannas.kesmen@gmail.com \\ Peter Ayuba Mellemut \\ Department of Christian Religious Education, School of Arts/Social Sciences, Federal \\ College of Education, Pankshin, Plateau State of Nigeria \\ peeterayubamellemut@gmail.com
}

\begin{abstract}
Purpose: This research is being carried out to critically examine the effects of Christian religious studies literacy on academic achievement with a particular reference to Quaan-pan Local Government Area of Plateau State of Nigeria. The researchers deem this research work necessary because of regular massive failure witnessed in CRS results in both WAEC and NECO. Most times, students have to depend on examination malpractices in order to pass exam in Quaan-pan LGA.
\end{abstract}

Methodology: In order for this objective to have been assessed, three research questions were formulated. The data that was collected is being analyzed by using simple percentages and tables for the research questions to be analyzed. A structured questionnaire is being used as the major instrument of data collection from the respondents in selected secondary schools in Quaan-pan Local Government Area of Plateau State to ascertain whether there is some level of knowledge that are acquired by Christian religious studies students in Quaan-pan Local Government Area of Plateau State.

Findings: The study found out that the effects associated with Christian religious studies prompted this study and the mass failure of students in CRS is due to lack of relevant effective teaching method for the subject. The challenges ranging from poor understanding of pedagogical and theological aims of the subject, societal moral decadence, lack of passion and love for students and the job, poor communication technique to vast and abstract nature of the subject. Solutions to these inadequacies have also been sought; hence the need to adhere strictly to the demands of stakeholders in education of children, because factors affecting teachers' preparation and execution of their lesson plans effectively jeopardize the aim of establishing the subject.

Unique contribution to theory, practice and policy: The study is being concluded with some recommendations that would require school managers to not only organize, but encourage CRS teachers to attend workshops, conferences and seminars, because the task of molding human behaviour is dynamic; hence regular attendance to conferences, seminars and workshops will equip them with new approaches and methods for effective implementation of CRS curriculum among students.

Keywords: Regular, Massive, Failure, Teacher-centered method, interactive Student centered method, \& Moral virtues. 


\section{INTRODUCTION}

The high level of moral decadence and insurgencies in Nigerian nation is an indication that there is poor religious teaching in secondary school system. Christian religious studies (CRS) as one of the religious subjects taught in secondary school in Nigerian takes a central stage in ensuring moral and spiritual wellbeing of individuals in the society. The key role of CRS in equipping the individuals and ensuring high level of morality is made clear in the objectives of CRS at the senior secondary level which include. Provision more opportunities for Nigerian youths to learn more about God and thereby develop their faith in God; to enable the youths to accept Christ as their savior; to help the youths develop Christian attitude and moral values (such as humility, respect, love, and justice, etc.); to instill in the youth the spirit of tolerance, reconciliation, peaceful co-existence and non-violence as well as to develop and foster in the youth the spirit of respect for all people and human life (Universal Basic Education Curriculum (UBE, 2013).

Organizing for effective teaching of Christian Religious studies is centered on certain factors such as "what to teach", "when to teach" and "how to teach". The teacher does not only teach the most relevant, meaningful and useful materials for specific students, he must also recognize and adopted a good and well-researched method of teaching that guarantees better understanding and also stimulates and motivate students' achievement (Abdukamid, 2010). No teacher enjoys watching students regularly fail examination. Parents and well-wishers in Quaan-pan LGA are getting discouraged of paying tuition to their wards for lack of knowledge and good results. Some have literally stopped their children from going to schools. This trend cannot continue under the watch of teachers. Researchers must stand fast to find a solution to it the enigma. This is why we are out to discover the cause and suggest solutions.

Academic achievement is the degree or level of success attained at the end of an academic endeavour (Omebe, 2005). The yardstick for measuring one's level of academic achievement is by assessing the academic performance of the individual through test and observation. He further explained that academic achievement has three dimensions such as high, average and low academic achievement. Academic achievement helps in proper evaluation of students and identification of their strength and weakness. However, in the context of this study, academic achievement is the relative change in behaviour of students as a result of effective teaching and learning of CRS in secondary schools.

The regular massive failure of students is CRS subjects in WAEC and NECO in most schools in Plateau state has become a matter of concern. The failure rate is most alarming in Quaanpan LGA. This is why the researchers have embarked on a research work centering on Government Secondary School, (GSS) Kwa, GSS Doemak, GSS Kwalla, GSS Kurgwi, and GSS Kwande. The importance of CRS in the present social, political and religious crisis in Nigeria cannot be over emphasized. Nevertheless, the trend of poor academic achievement among students over the years seems to be on the increase. It may be due to teachers' use of lecture method of teaching which has been the prevalent mode of lesson presentation in secondary schools in Nigeria. This method is teacher-centered and does not inspire and motivate students' interest towards the learning of the subject in senior secondary schools. The students may end up therefore having low interest which could lead to poor achievement in CRS in schools. Therefore, this research seeks to examine the effect of Christian Religious studies literacy on the academic achievement of secondary school students: a case study of SS I student in Quaan-pan L.G.A of Plateau State. 


\section{Purpose of the Study}

The objective of this study is to research on why students in Quaan-pan LGA fail CRS in both WAEC and NECO as massively as they do. We will study the skills of the teachers, their methodology and also check students' motivation or interest in the course. We will determine the skills possessed by Christian religious studies students, students and Examine the factors affecting the students in acquiring knowledge acquired from Christian religious studies in Quaan-pan Local Government Area of Plateau State. We will then make suggestions regarding the way forward which will help opinion leaders in making employment decisions.

\section{Research Questions}

The following research questions were stated to guide this study:

1. Are there skills possessed by Christian religious studies students in Quaanpan Local Government Area of Plateau State?

2. Are there knowledge acquired by Christian religious studies students in Quanpan Local Government Area of Plateau State?

3. Are there factors affecting the students in acquiring knowledge acquired of Christian religious studies in Quaan-pan Local Government Area of Plateau State?

\section{Theoretical/Conceptual Analysis}

This study presents a review of related literature by making use of Horton's (2006) pp. 639676) theoretical and conceptual analysis on Christian Education and its definition, Learning styles, Cross-Cultural perspectives and Christian Formation, with particular application AL reference to some selected Senior Secondary School Students from Quaan-pan Local Government Area of Plateau State of Nigeria. Views and opinions of other authors will be presented as follows:

\section{Concept of Christian Religious Studies}

Christian Religious Studies is one of the subjects taught in secondary schools in Nigeria. The teaching of the Christian Religious Studies (CRS) could be dated back as 19th century with the pioneers of Nigerian Education (Banjo, 2003). In attempting to discuss the concept of Christian Religious Studies beneficially, it is imperative, to begin by clarifying various terms with rigor and exactitude to avoid any possible news conceptions in the mind of any reader. The word 'Christian' etymologically comes from this Greek words 'Christian' and Christos; meaning "follower of Christ" and anointed one", it is used three times in the New testament of the Bible (Act11:28, 1 Peter 4:16). The Bible tells us "it was in Antioch of Syria that the followers of Jesus were first called "Christian". The question that borders the mind of the reader, which the researchers consider in this definition process, is "who is a Christian? The answer to this question can be formulated only in a cumulative fashion. Thus a Christian is a social human person in whom God is present in grace but who is at the same time, prone to act against the, divine preference. Israel (2011) states that a Christian is one who professes and belief in Jesus Christ or fellows the religion based on the life and teachings of Jesus Christ. Anole added that a Christian is a person who adheres to Christianity and Abraham's monotheistic religion based on the life and teaching of Jesus of Nazareth, whom Christians belief is the Messiah. Okoro (2010) opines that a Christian is a particular kind of human 
being, not in the sense that a Christian has a different biological or psychic structure, but in the sense that a Christian has moved to a different level of human consciousness. Anih (2010) equally state that a Christian is a follower of Jesus Christ, that a person who believes and practices the tenets of the Christian faith in the Holy Scripture (Bible). However, in the context of this study, a Christian is referred to as a student who practices Christianity and learns it in school as one of the religions in the world. Religion in the other way has been heated with lots of debate about the meaning and its practices in human society. Its etymology can help to define the concept.

Religion is derived from the Latin noun 'religio', but with some ambiguities arising from these different verbs that are allied with the noun - 'religion' (to turn constantly" or to observe conscientiously") 'religari [to bind on self-] (back) and 'religere' ("to choose again") (Okoro, 2010). Each of these verbs according to Okoro points to three possible religious attitudes. Though it is not clear from which verb the noun is derived, each of the verbs is consistent with the view that religion "is a relationship to God." Okoro (2010) says that religion thus has to do with the whole human existence, and not merely with some special sector of it. He further stresses that religion is the whole complex of attitudes, convictions, emotions, gestures, rituals, beliefs and institutions by which we come to terms with and express our most fundamental relationship with reality (God and the created order, perceived as coming from God's creative hand). Religion therefore, presupposes and flows from faith. It is an individual social and institutional manifestation of some implicit faith in God. Religion does not only have to do with the impact of the holy upon us, but with human responses to the holy as well. From these thought there is no doubt on the saying that a religion without the element of the Divine is like a house without foundation. Religion in line with etymology viewpoint is the medium through which man unites himself with God in worship, adoration and service. Anih (2010) maintains that religion refers to both personal practices related to communication stemming from shared conviction. It is often described as a communal system for the coherence of belief focusing on a system that is considered to reverence for a supernatural power or powers regarded as creator or governor of the universe. Religion therefore, has to do with the whole of human existence, and not merely with some special sector of it. In the context of this study, religion is conceived as the belief in the teaching of Jesus Christ such as love, provision, protection, leadership and the nature of Heavenly Kingdom among other things which help people to live peacefully and harmoniously in the society.

Christian religious studies is an aspect of learning that deals with the inculcating in the students, certain elements of education, intellectual theory and practices of Christ as contained in the Holy Bible. Eluu (2011) defines Christian Religious Studies as the education for the development of spiritual, moral and mental, growth of pupils or students" in essence, Christian religious studies are expected to give children an understanding of the universe and the interpersonal relationship between human beings and the supreme beings. Ugwu (2001) opines that CRS is a type of religious studies that bases its teachings in the life and teaching of Jesus Christ. Ali and Akubue in Njoku (2009) observe that Christian religious studies is a subject which aims at developing and fostering in the lives of the students Christian attitudes and values such as respect for life, obedient to constituted authority, responsible self, selfless services to God and humanity. They further said that CRS is an academic discipline that is designed to provide the learner with moral and spiritual transformation. In the context of this study, the researchers viewed CRS as a social science subject that teaches students good moral behaviour, fearing of God, knowledge and skills that will make them to contribute their 
quota in socio-economic, political and moral development in senior secondary schools in Nigeria.

\section{Aims/Objectives of Christian Religious Studies}

In the past, several aims were proposed for Christian religious studies in Nigerian secondary schools. Such of these aims is briefly discussed below according to Gotan (2005):

To teach the bible: CRS as an academic field of study aims at teaching the student the Bible contents. Rani in Ugbo (2003) opines that the Bible is the master textbook and in fact, in most times, the title given to the subject was Bible.

To teach morals: The teaching of morals has been a long-standing aims recommended for teachers of Christian religious studies in secondary schools and other institutions of learning (Nwachukwu, 2010). Morality is a very important concept especially in this era of moral decadence all over the world. Moral education as over the years impacted largely through literature in the forms of legend about the Gods and heroes of Greece (Gotan, 2005). Gottan admits that in the Judeo-Christian tradition the link between morality and religions has been so close that people still regard them as inseparable. Gotan (2005) maintains that to admit logical distinction between religion and morality does not, however, mean that they are antagonistic realms of human experience or that their objectives are mutually exclusive

To teach catechism or Christian nurture: The view that CRS aims at teaching catechism or Christian nurture underlies the frequent demand by the various churches that Christian religious studies in schools should be given to their adherents by teachers who are members of their own religious denomination. The view seeks to awaken, nourish and develop one's personal belief and to hand on the received tradition so as to build up the ecclesial community (Morgan, 2006). Although, most religious educators today, however, insist that confessional teaching of religion is not appropriate in the school's content, its parochial nature offers scope for dealing with the practical problems of religious diversity in modern pluralistic societies.

Obilon in Eluu (2009) states that the aims of teaching Christian religious studies in Nigerian schools is to educate the Nigerian children both morally and intellectually, and instill in them the desire to be good citizens". So, through guidance and supervision of their conducts, the children are encouraged to develop a right attitude towards life, their environment, interpersonal relationship and community living. Eluu (2009) maintains that Christian religious studies aims at making the children have faith in God, speak to Him in prayers, and trust Him for all their needs as they work and pray. Through the teaching of Christian Religious Studies, students take decisions and develop their mind on how to withstand the emotional problems associated with every day-to-day life. Christian Religious Studies therefore, becomes a worthwhile school activity because of the values it has for the society. Eluu (2009) adds that the teaching of Christian religious studies in school also leads pupils to raise fundamental questions relating to life and existence. For examples, who is God? Does God exist? Where is God? Why am I here? What is going to be my end? What am I supposed to do? etc. the transmission of acceptable moral standards in the society cannot be over emphasized. Through the teaching of CRS subject, children are encouraged to express their faith and to develop talents and thus prepare themselves for useful living in the society (FRN, 2004). Ali and Akubue in Njoku (2009) maintain that the curriculum aims of CRS is to develop and foster in the life of the students Christian attitudes and values such as respect for life, obedient to constituted authority, responsible self, selfless services to God and humanity. 
They further say that CRS is an academic discipline that aims at providing learner with moral and spiritual transformation.

The teaching and learning of CRS in secondary schools in Nigeria has the following objective of Christian religious studies. These are:

1) To inculcate the knowledge of the Bible and fear of God in the Learner.

2) Inculcate moral virtue in learners.

3) Need to develop tolerance for other religions.

4) Creating a disciplined society and responsible citizenry.

5) Development of integrated, spiritual potentials and problem solving abilities (Okoro, 2010).

It is expected that for these objectives to be achieved, adequate teaching and learning strategy and method is required hence, it is the surest means of cultivating and shaping the students' behaviour. This idea on how to achieve the objective of CRS in schools has made the federal government of Nigeria in her national policy on education of 2004 specifically states that moral or religion instructions should be taught in school through the study of the biographies of great people, studies and practices of Religion, discipline, games and other activities that involves team work (FME, 2004:20).

\section{Teaching of CRK at Senior Secondary School Level}

Teaching of CRK at Senior Secondary School level is aimed at achieving the objectives of the discipline at that level which include, preparation for useful living within the society, and, preparation for higher education (FRN, 2004). The National Curriculum of Bible Knowledge (or CRK) for senior Secondary Schools (1985) listed the objectives to guide the teaching of the subject as follows:

i. To provide more opportunities for the Nigerian youths to learn more about God and thereby develop their faith in Him.

ii. To enable the youth to accept Christ as Lord and savior.

iii. To enable the youth to recognize Jesus as the founder and sustainer of the Christian church.

iv. To enable the youth to accept the guidance of the Holy Spirit in their daily activities.

v. To help the youth to understand the basic teachings of Christ and to apply these to their daily lives and work, and

vi. To develop in the youth Christian attitudes and values such as humility respect love, kindness, justice and fair play, spirit of forgiveness, obedience, devotion to duty, orderly behavior and selfless service to God and humanity.

The Senior Secondary School Christian Religious Studies curriculum further emphasizes the relationship between Religion and morality, between God and Man, and presents God as the creator of all mankind, the sustainer of human lives and the sources of the Christian belief, joy and hope. The content is organized in years of study, while the learning experiences are organized in themes. The curriculum is also organized in specific format of six vertical columns, namely, unit, objectives, content, teaching methods and activities, suggested 
teaching aids and evaluation. This arrangement is aimed at making teaching of CRS effective for curbing insurgency and other criminal activities in Nigeria.

Different strategies for classroom pedagogy of CRS consist of a combination of certain specific operations such as carefully developed lecture methods, questioning technique, project method, discussion method, inquiry method, field trips and assignment method. CRS, as a result of its peculiar nature, goes beyond affective domain to touch on man's spiritual realm; eclectic approach is thus recommended for its pedagogy, that is, variety of methods should be employed in a given lesson period (Ekpunobi, in Eluu 2011).

\section{Academic Achievement of CRS Students}

Academic Achievement is the degree or level of success attained at the end of an academic endeavor (Omebe, 2005). The yardstick for measuring one's level of academic Achievement is by assessing the academic Achievement of the individual through test and observation. He further explained that academic Achievement has three dimensions such as high, average and low academic Achievement. Academic Achievement helps in proper evaluation of students and identification of their strength and weakness. However, in the context of this study, academic Achievement is the relative change in behaviour of students as a result of effective teaching and learning of CRS in Secondary Schools.

Afonga, (2002) notes that methodology is key to success in learning. When the method is poor, student despair learning. The issue of high or low academic Achievement of Secondary School students in CRS has been attributed to some factors such as the school environment, peer influence, the family dynamics, etc (Ekeh and Njoku, 2013). But, of all these factors, the researchers feel that role-play method of teaching play a key role in relation to students' academic Achievement in CRS. Role-play method is a dramatic and innovative training technique which helps students to develop both cognitive and affective components of perception and helps in knowing how people behave and why people behave in different ways (Charturvedi, 2009). Obanya (2004) maintains that role-playing activities introduce students to "real world" situations. This indicates that role-playing is highly motivating as the majorities of students enjoy these types of activities and become more inspired learners.

Students' interest is another factor that determines students' academic Achievement in schools. Interest can be defined as a psychological state of having an affective reaction to and focused attention for particular content and/or the relatively enduring predisposition to re-engage particular class of objects events, or ideas (Omebe, 2005). Long (2007) defines interest as the formation of a relationship between a person and an object. Interest could also be essentially a function of the perceived likelihood to succeed on a specific group of tasks and the value of a consequence of doing well. According to Ainley (2002), morality is also an important key to success in delivering and understanding learning. The way each person learns depends on interest. For instance, some students prefer to learn complete subject matter by heart while others search for meaning. Students' differences in learning preferences have often been related to a number of individual factors such as motivation and perception of one's ability. Interest is very important in one's educational and life success.

\section{Methodology}

This research adopts a survey design method, which is used in finding out views, opinions and facts from knowledgeable people called the population using a representative selected from such population called sample for the purpose of investigation. The populations for this 

study are the students of selected secondary schools in Quaan-pan L.G.A, namely: GSS, Kwa, GSS, Doemak, GSS, Kwalla GSS, Kurgwi, and GSS, Kwande respectively. Simple random sampling is used to select 100 respondents from selected secondary schools in Quaan-pan L.G.A whereby, 20 students were selected from each school in Quaan-pan L.G.A. The research instrument that was used in this study is questionnaire; the questionnaire contains two sections that is, section A\&B. Section A deals with personal data of the respondents, while section $\mathbf{B}$ items contains questions with 4 Likert scale, which is: Strongly Agree (SA), Agree (A), Disagree (D), and Strongly Disagree (SD). The researchers used the arithmetic mean method to compute the data.

The research was carried out and discussed under the following headings: research design, population, sample and sample techniques, instrumentation, and procedure for data collection, procedure for data analysis, reliability and validity.

\section{Population of the study}

The population for the study comprises of 5 secondary school students in Quaan-pan Local Government Area of Plateau State.

\section{Sample of the study}

Sample is a selected number of individuals that are carefully chosen by the researchers to represent the entire research population. The sample size of the research work is twenty (20) students selected from each of the school to make the total of hundred (100). This sample therefore enables the researchers to generalize the findings on the whole population effectively.

\section{Sampling techniques}

The sample for this study comprises Hundred (100) participants which were randomly selected from 5 secondary school students in Quaan-pan Local Government Area of Plateau State. Five (5) secondary schools were selected from Quaan-pan Town through stratified random sampling techniques. One hundred (100) senior secondary school students were selected from five (5) selected schools through stratified random techniques.

\section{Instrument for data analysis}

The instrument used by the researchers was mainly the questionnaire meant for the students and teachers of the selected secondary schools in Quaan-pan Local Government Area of Plateau State. The researchers assumed that the information derived from their responses will be valuable as they are those who are directly involved in the study. The items are presented in declarative statements followed by responses option that indicate varying degrees of agreement. Respondents were required to respond on SA $=$ Strongly Agree $-4, \mathrm{~A}=$ Agree -3 , $\mathrm{D}=$ Disagree $-2, \mathrm{SD}=$ Strongly Disagree $=1$.

\section{Procedure for data collection}

The researchers visited all the selected secondary schools in Quaan-pan Local Government Area of Plateau State to administer the questionnaire. One hundred and forty (20) copies of the questionnaire were administered directly to students after which they were collected at the same day.

\section{Validity of instrument}

For content and face validity of the instruments that was designed for the study, the researchers gave the instruments to experts in the field of educational psychology and experts in the area of Integrated Science Education. After all these people had given their suggestions 
and made necessary corrections on the instrument, the researcher then subjected it to the colleagues who made the final corrections.

\section{Reliability of instrument}

After content and face validity of the instruments, twenty (20) copies of the instruments were administered in order to re-establish the psychometric property of the instrument. The Cronbach alpha technique was then used to test their reliability to ensure that they are consistent in measuring what they were designed to measure.

\section{Procedure for data collection}

The instruments were administered to the participants on the day approved by the school authorities for the exercise. The researchers were assisted by trained research assistants in the administration and collection of the instruments. In each of the selected school, the administration and collection of instruments were done on the same day of administration. The instrument was administered on the participants in their various schools by the researchers with the support of the trained research assistants in the schools.

\section{Method of data analysis}

Analysis of the gathered information as regards the study was based on the use of frequency tables and percentages technique. The frequencies of responses would be found, the scores would be expressed in percentages and presented in tabular forms as shown below. These results would be presented on the basis of the formulated research questions to show whether or not the research questions should be upheld.

\section{Results}

The results are hereby organized in the tables below. Please, note that each table is followed by foot notes, briefly describing or interpreting the results.

Table 1; Response Rate to Opinions: Teachers inculcate knowledge of the Bible and fear of God in Learners.

\begin{tabular}{llll}
\hline S/N & Opinion & Respondent & Percentage \\
\hline $\mathbf{1}$ & SA & 32 & $32 \%$ \\
$\mathbf{2}$ & A & 17 & $17 \%$ \\
$\mathbf{3}$ & D & 36 & $36 \%$ \\
$\mathbf{4}$ & SD & 15 & $15 \%$ \\
\hline & Total & 100 & $100 \%$ \\
\hline
\end{tabular}

Table 1 shows that 32 respondents representing 32\% strongly agree that teachers inculcate the knowledge of the Bible and fear of God in learners, 17 respondents representing 17\% agree with the statement, while 36 respondents representing 36\% disagree and 15 respondents representing $15 \%$ strongly disagree. From the above analysis majority of the respondents disagree that teachers inculcate the knowledge of the Bible and fear of God in learners.

Table 2; Response Rate to Opinions: Teachers inculcate moral virtues in learners

\begin{tabular}{llll}
\hline S/N & Opinion & Respondent & Percentage \\
\hline $\mathbf{1}$ & SA & 41 & $41 \%$ \\
$\mathbf{2}$ & A & 23 & $23 \%$ \\
$\mathbf{3}$ & D & 12 & $12 \%$ \\
$\mathbf{4}$ & SD & 24 & $24 \%$ \\
\hline & Total & 100 & $100 \%$ \\
\hline
\end{tabular}


Table 2 shows that 41 respondents representing $41 \%$ strongly agree that teachers inculcate moral virtues in learners, 23 respondents representing $23 \%$ agree with the statement, 12 respondents representing $12 \%$ disagree and 24 respondents representing $24 \%$ strongly disagree. From the above analysis, it reveals that majority of the respondents strongly agree that teachers inculcate moral virtues in learners.

Table 3; Response Rate to Opinions: Teachers need to develop tolerance for other religions

\begin{tabular}{llll}
\hline S/N & Opinion & Respondent & Percentage \\
\hline $\mathbf{1}$ & SA & 11 & $11 \%$ \\
$\mathbf{2}$ & A & 12 & $12 \%$ \\
$\mathbf{3}$ & D & 32 & $32 \%$ \\
$\mathbf{4}$ & SD & 45 & $45 \%$ \\
\hline & Total & 100 & $100 \%$ \\
\hline
\end{tabular}

Table 3 shows that 11 respondents representing $11 \%$ strongly agree that teachers need to develop tolerance for other religions, 12 respondents representing 12\% agree, 32respondents representing 32\% disagree and 45 respondents representing $45 \%$ strongly disagree. From the above analysis it indicates that majority of the respondents strongly disagree that teachers need to develop tolerance for other religions.

Table 4; Response Rate to Opinions: Teachers create a disciplined society and responsible citizenry

\begin{tabular}{llll}
\hline S/N & Opinion & Respondent & Percentage \\
\hline $\mathbf{1}$ & SA & 40 & $40 \%$ \\
$\mathbf{2}$ & A & 38 & $38 \%$ \\
$\mathbf{3}$ & D & 12 & $12 \%$ \\
$\mathbf{4}$ & SD & 10 & $10 \%$ \\
\hline & Total & 100 & $100 \%$ \\
\hline
\end{tabular}

Table 4 shows that 40 respondents representing $40 \%$ strongly agree with the statement that teachers create a disciplined society and responsible citizenry, 38 respondents representing $38 \%$ agree, while 12 respondents representing $12 \%$ disagree and 10 respondents representing $10 \%$ strongly disagree. From the above analysis it indicates that majority of the respondents strongly agrees that teachers create a disciplined society and responsible citizenry.

Table 5; Response Rate to Opinions: Teachers' development of integrated, spiritual potentials and problem solving abilities in learners is important

\begin{tabular}{llll}
\hline $\mathbf{S} / \mathbf{N}$ & Opinion & Respondent & Percentage \\
\hline $\mathbf{1}$ & SA & 45 & $45 \%$ \\
$\mathbf{2}$ & A & 35 & $35 \%$ \\
$\mathbf{3}$ & D & 8 & $8 \%$ \\
$\mathbf{4}$ & SD & 12 & $12 \%$ \\
\hline & Total & 100 & $100 \%$ \\
\hline
\end{tabular}

Table 5 shows that 45 respondents representing $45 \%$ strongly agree with the statement that teachers' development of integrated, spiritual potentials and problem solving abilities is important, 35 respondents representing 35\% agree, 8 respondents representing $8 \%$ disagree and 12 respondents representing $12 \%$ strongly disagree. From the above analysis, it reveals 
Vol.8, Issue 1, No.1, pp 1-19, 2022

that majority of the respondents strongly agree that teachers' development of integrated, spiritual potentials and problem solving abilities is important.

Table 6; Response Rate to Opinions: Christian religious studies does not appeal to one's area of interest

\begin{tabular}{llll}
\hline S/N & Opinion & Respondent & Percentage \\
\hline $\mathbf{1}$ & SA & 9 & $9 \%$ \\
$\mathbf{2}$ & A & 11 & $11 \%$ \\
$\mathbf{3}$ & D & 25 & $25 \%$ \\
$\mathbf{4}$ & SD & 55 & $55 \%$ \\
\hline & Total & 100 & $100 \%$ \\
\hline
\end{tabular}

Table 6 shows that 9 respondents representing 9\% strongly agree that CRS does not appeal to one's area of interest, 11 respondents representing $11 \%$ agree with the statement, 25 respondents representing 25\% disagree and 55 respondents representing 55\% strongly disagree. From the above analysis, it reveals that majority of the respondents strongly disagree that CRS does not appeal to one's area of interest.

Table 7; Response Rate to Opinions: Teaching of CRS is generally boring

\begin{tabular}{llll}
\hline S/N & Opinion & Respondent & Percentage \\
\hline $\mathbf{1}$ & SA & 23 & $23 \%$ \\
$\mathbf{2}$ & A & 33 & $33 \%$ \\
$\mathbf{3}$ & D & 31 & $31 \%$ \\
$\mathbf{4}$ & SD & 13 & $13 \%$ \\
\hline & Total & 100 & $100 \%$ \\
\hline
\end{tabular}

Table 7 shows that 23 respondents representing 23\% strongly agree with the statement that teaching of CRS is generally boring, 33 respondents representing 33\% agree, 31 respondents representing $31 \%$ disagree and 13 respondents representing $13 \%$ strongly disagree. From the above analysis, it indicates that majority of the respondents agree that teaching of CRS is generally boring.

Table 8; Response Rate to Opinions: CRS teachers are disliked

\begin{tabular}{llll}
\hline S/N & Opinion & Respondent & Percentage \\
\hline $\mathbf{1}$ & SA & 25 & $25 \%$ \\
$\mathbf{2}$ & A & 36 & $36 \%$ \\
$\mathbf{3}$ & D & 23 & $23 \%$ \\
$\mathbf{4}$ & SD & 16 & $16 \%$ \\
\hline & Total & 100 & $100 \%$ \\
\hline
\end{tabular}

Table 8 shows that 25 respondents representing $25 \%$ strongly agree with the statement that CRS teachers are disliked, 36 respondents representing $36 \%$ agree, 23respondents representing $23 \%$ disagree and 16 respondents representing $16 \%$ strongly disagree. From the above analysis, it reveals that majority of the respondents agree that CRS teachers are disliked. 
Table 9; Response Rate to Opinions: Time allocated to teaching of CRS in schools is not motivating.

\begin{tabular}{llll}
\hline S/N & Opinion & Respondent & Percentage \\
\hline $\mathbf{1}$ & SA & 49 & $49 \%$ \\
$\mathbf{2}$ & A & 33 & $33 \%$ \\
$\mathbf{3}$ & D & 12 & $12 \%$ \\
$\mathbf{4}$ & SD & 6 & $6 \%$ \\
\hline & Total & 100 & $100 \%$ \\
\hline
\end{tabular}

Table 9 shows that 49 respondents representing $49 \%$ strongly agree with the statement that time allocated to teaching of CRS in schools is not motivating, 33 respondents representing $33 \%$ agree, then 12 respondents representing 12\% disagree and 6 respondents representing $6 \%$ strongly disagree. From the above analysis, majority of the respondents strongly agree that time allocated to teaching of CRS in schools is not motivating.

Table 10; Response Rate to Opinions: Teachers are unable to integrate faith and life situations in teaching the subject

\begin{tabular}{llll}
\hline S/N & Opinion & Respondent & Percentage \\
\hline & SA & 8 & $8 \%$ \\
$\mathbf{2}$ & A & 13 & $13 \%$ \\
$\mathbf{3}$ & D & 25 & $25 \%$ \\
$\mathbf{4}$ & SD & 54 & $54 \%$ \\
\hline & Total & 100 & $100 \%$ \\
\hline
\end{tabular}

Table 10 shows that 8 respondents representing $8 \%$ strongly agree that Teachers are unable to integrate faith and life situations in teaching the subject, 13 respondents representing 13\% agree while 25respondents representing 25\% disagree and 54 respondents representing 54\% strongly disagree. From the above analysis, it reveals that majority of the respondents strongly disagree that Teachers are unable to integrate faith and life situation in teaching the subject.

Table 11; Response Rate to Opinions: One's future career requires the choice of CRS as a subject

\begin{tabular}{llll}
\hline S/N & Opinion & Respondent & Percentage \\
\hline $\mathbf{1}$ & SA & 39 & $39 \%$ \\
$\mathbf{2}$ & A & 31 & $31 \%$ \\
$\mathbf{3}$ & D & 12 & $12 \%$ \\
$\mathbf{4}$ & SD & 18 & $18 \%$ \\
\hline & Total & 100 & $100 \%$ \\
\hline
\end{tabular}

Table 11 shows that 39 respondents representing $39 \%$ strongly agree with the statement that one's future career requires the choice of CRS as a subject, 31 respondents representing $31 \%$ agree, then 12 respondents representing 12\% disagree and 18 respondents representing $18 \%$ strongly disagree. From the above analysis, majority of the respondents strongly agree that one's future career requires the choice of CRS as a subject. 
Table 12; Response Rate to Opinions: People who have studied CRS are trusted in their respective careers

\begin{tabular}{llll}
\hline S/N & Opinion & Respondent & Percentage \\
\hline $\mathbf{1}$ & SA & 23 & $23 \%$ \\
$\mathbf{2}$ & A & 32 & $32 \%$ \\
$\mathbf{3}$ & D & 21 & $21 \%$ \\
$\mathbf{4}$ & SD & 24 & $24 \%$ \\
\hline & Total & 100 & $100 \%$ \\
\hline
\end{tabular}

Table 12 shows that 23 respondents representing $23 \%$ strongly agree with the statement that People who have studied CRS are trusted in their respective careers, 32 respondents representing 32\% agree, then 21 respondents representing $21 \%$ disagree and 24 respondents representing $24 \%$ strongly disagree. From the above analysis, majority of the respondents agree that People who have studies CRS are trusted in their respective careers.

Table 13; Response Rate to Opinions: Discipline in CRS enables one to uphold ethical values which are required in work places

\begin{tabular}{llll}
\hline S/N & Opinion & Respondent & Percentage \\
\hline $\mathbf{1}$ & SA & 36 & $36 \%$ \\
$\mathbf{2}$ & A & 31 & $31 \%$ \\
$\mathbf{3}$ & D & 13 & $13 \%$ \\
$\mathbf{4}$ & SD & 20 & $20 \%$ \\
\hline & Total & 100 & $100 \%$ \\
\hline
\end{tabular}

Table 13 shows that 36 respondents representing $36 \%$ strongly agree with the statement that discipline in CRS enables one to uphold ethical values which are required in work places, 31 respondents representing 31\% agree while 13 respondents representing $13 \%$ disagree and 20 respondents representing 20\% strongly disagree. From the above analysis, it reveals that majority of the respondents strongly agree that discipline in CRS enables one to uphold ethical values which are required in work places.

Table 14; Response Rate to Opinions: discipline in CRS enables one to have good moral conduct.

\begin{tabular}{llll}
\hline S/N & Opinion & Respondent & Percentage \\
\hline $\mathbf{1}$ & SA & 41 & $41 \%$ \\
$\mathbf{2}$ & A & 32 & $32 \%$ \\
$\mathbf{3}$ & D & 18 & $18 \%$ \\
$\mathbf{4}$ & SD & 9 & $9 \%$ \\
\hline & Total & 100 & $100 \%$ \\
\hline
\end{tabular}

Table 14 shows that 41 respondents representing $41 \%$ strongly agree with the statement that discipline in CRS enables one to have good moral conduct, 32 respondents representing 32\% agree, then 18 respondents representing 18\% disagree and 9 respondents representing 9\% strongly disagree. From the above analysis, majority of the respondents strongly agree that discipline in CRS enables one to have good moral conduct. 
Table 15; Response Rate to Opinions: CRS teaches principles which are necessary for career development

\begin{tabular}{llll}
\hline S/N & Opinion & Respondent & Percentage \\
\hline $\mathbf{1}$ & SA & 41 & $41 \%$ \\
$\mathbf{2}$ & A & 32 & $32 \%$ \\
$\mathbf{3}$ & D & 17 & $17 \%$ \\
$\mathbf{4}$ & SD & 10 & $10 \%$ \\
\hline & Total & 100 & $100 \%$ \\
\hline
\end{tabular}

Table 15 shows that 41 respondents representing $41 \%$ strongly agree that CRS teaches principles which are necessary for career development, 32 respondents representing 32\% agree with the statement, while 17 respondents representing $17 \%$ disagree and 10 respondents representing $10 \%$ strongly disagree. From the above analysis, majority of the respondents strongly agree that CRS teaches principles which are necessary for career development.

\section{Discussion of Findings}

Analysis has been made to establish the effect of Christian Religious Studies literacy possessed by secondary school students on their academic achievement in Quaan-pan Local Government Area of Plateau State. These various aspects of the academic achievements range from level of education of parents, family size, parental occupation and motivation and availability of learning materials in school. The data obtained and the analysis was based on some selected schools in Quaan-pan Local Government Area. The analysis showed that Religious training and moral instruction was considered as fundamental to the development of sound education.

Table 2 stated that teachers inculcate moral virtues in learners. The teaching of morals has been a long-standing aims and objectives recommended for teachers of Christian Religious Studies in Secondary Schools and other institutions of learning (Nwachukwu, 2010). Morality is a very important concept, especially in this era of moral decadence all over the world. Table 3 indicates that teachers need to develop tolerance for other religions, the study revealed that teachers do not have tolerance for other religions, each teacher has his/her own policies for talking about different faiths and religions in the classroom. Some may say that students should check their faith at the door(Johnson,2018). In some cases, addressing religious differences and teaching about the faiths of others can have an immediate effect on the students in schools. The issue of high or low academic Achievement of Secondary School students in CRS has been attributed to some factors such as the school environment, peer influence, the family dynamics, etc. (Ekeh and Njoku, 2013). But, of all these factors, the researchers feel that method of teaching play a key role in relation to students' academic Achievement in CRS.

\section{Unique contribution to theory, practice and policy}

The study would be beneficial to students, teachers, religious instructors, curriculum planners, educational administrators, researchers and textbook authors. To students, the study would help to improve their understanding of CRS and thus adjust properly in the society through active participation in the classroom learning which will stimulate their interest and change the negative perceptions they already have in learning CRS and this invariably will help them to develop the affective domain of knowledge in secondary schools. They would equally perform better in internal and external examinations without depending on 
examination malpractice which have been the problem in the educational sectors. This is because the students stand the chance of becoming masters on their own through involvement in different roles in the classroom. The findings of the study would help teachers to have an insight into the meaning, application and problems of using different method of teaching and thus change their methods when the need arises for proper students' achievement and interest in CRS in secondary schools. The relevance of effective method in the implementation of Christian religious studies in secondary school would be made known to teachers as they are the chief implementers of planned curriculum of schools. This could be done by teachers observing the students performing their roles and equally identify their individual problem in using the method in the teaching and learning of CRS in secondary schools.

Religious instructors and bodies are not left out as they would understand the best way to educate children in the principles and practice of Christianity which invariably will promote peace and harmony as well as co-existence in the Nigerian society. Curriculum planners or designers would be made to understand curriculum problems that affect the application of effective teaching method in secondary schools especially in Plateau State.

\section{Conclusion}

Based on findings of this study, it is concluded that the effects associated with Christian religious studies prompted this study and the mass failure of students in CRS is due to lack of relevant effective teaching method for the subject. The challenges ranging from poor understanding of pedagogical and theological aims of the subject, societal moral decadence, lack of passion and love for students and the job, poor communication technique to vast and abstract nature of the subject. Solutions to these inadequacies have also been sought; hence the need to adhere strictly to the demands of stakeholders in education of children, because factors affecting teachers' preparation and execution of their lesson plans effectively jeopardize the aim of establishing the subject. This otherwise mars the general aim of education, which is geared towards developing in man the knowledge and right attitude towards his/her neighbor.

\section{Recommendations}

Based on the findings of the study, the following recommendations are made:

There is need for the school managers to not only organize, but encourage CRS teachers to attend workshops and seminars because the job of molding human behavior is dynamic; hence regular attendance to seminars will equip them, with new approaches and methods for effective implementation of CRS curriculum among students. There is need for administrators to support the teaching of CRS in terms of provision of instructional materials and allocation of adequate time to the teaching of the subject. Governments, society and school managements should emphasize the teaching of the CRS in schools. In other words, greater emphasis on the importance of the subject should be required. The subject could be made compulsory at all levels of education like the use of English, bearing in mind the role that the subject is designed to achieve in the learners. Teachers of CRS as a matter of importance should be equipped through training and retraining so that they will be properly grounded in the pedagogical and theological aims of the subject. Effective teaching is dependent upon teachers' skills and knowledge; and these variable must be sorted out to enable the teaching of the subject achieve its set goals in the learners' lives.

\section{References}


Abayomi, S. (2004). Differences between Nigerian junior and senior pre-service teachers teaching science efficacy beliefs in Nigerian college of education. An unpublished $\mathrm{Ph} . \mathrm{D}$. project submitted to faculty of education, University of Nigeria Ibadan.

Abdulkamid, M. (2010). Methods of teaching science subjects in secondary schools in Sokoto municipals. Retrieved from www.htt://.mtsst./Abdulhamid.htm

Abonyi, S.O., Okereke, S.C., Omebe, C.A., \&Anugu, M. (2006). Foundation of educational research and statistics. Plateau: Fred-Ogah Publisher.

Adedeji, T. (2007). The Impact of motivation on students' achievement and learning outcomes in mathematics among secondary school students in Nigeria. Eurasia Journal of Mathematics \& Technical Education, 3(2). Pp 149-156.

Adukwu, R.M. (2004). CRK and instructional strategies: a simplified approach. Plateau: Calvary Printing and Publishing Company.

Afikinkpan, M. (1995). Investigation of the effect of student's attitude towards Christian religious knowledge in North and Bassa Local Government Area of Plateau State. Retrieved from http://www.satcrk.affinkikpan.htm on 24/10/2021.

Afonga, S. (2002). Mainstreaming gender in the university curriculum and administration. paper presented in seminar at the center for gender studies, OlabisiOnabanjo University Igo-Iwoye, Ogun State, Nigeria at the Annual Seminar of Social Science Academy, November 13, 2001.

Aguokogbuo, C. (2005). Issues in pre-primary and primary education in Nigeria. Nsukka: Mike Social Publishers.

Agwu, S.N. (2005). Strategies for teaching the arts and social sciences. Plateau: Pan-Africa Publishers.

Ainley, P.L. (2002). Intelligence, personality \& interest: evidence for overlapping traits. Psychological Bulletin, 121,219-245.

Ajah, E. \&Asadu, C.I. (2002). Effects of role-play method of instruction on students' achievement in senior secondary school Christian religious knowledge. Unpublished B.A Ed Project, Department of Arts Education, University of Nigeria, Nsukka.

Akubue, E. (2009). Correlates of students' academic achievement in senior secondary schools in Ijebu-Ode, Ogun State. European Scientific Journal 8(4). pp 1857-7881.

Alemika, E.E.O. (2013). Cost of insurgency in Nigeria. In M.D. Abubakar (ed). Nigeria Police Force: The J journey so far. 239-256. Abuja; Law Lords Publications.

Anih, S.A. (2010). Paradigm shift from teacher-centered to learner-centered education. Enugu: ATCOL Press.

Asalu V.C. (2005). Religion and society. Onitsha: Abbot Books Ltd.

Banjo, S.A. (2003). West African teachers' handbook. London: Hodder \&Stoughton Publishers.

Charturvedi, V. (2009). Role-play method: an innovative training techniques. Retrieved from: www.indiamba.com/../fc896.html Date: 23/9/21. 
Ede, V.I. \&Odo, A.E. (2006). Factors influencing student low interest in the study of CRK in secondary school in Isu-Uzo L.G.A. Unpublished B.A Ed Project, Department of Arts Education, University of Nigeria, Nsukka.

Ekeh, N. \& Njoku, C.N. (2013). Influence of school environment and family background on academic achievement of secondary school students. International Journal of Educational Research, University of Nigeria Nsukka, 11(1), pp 61-72

Eluu, P.E. (2001). Teaching religious studies in secondary schools in Nigeria: Problems and Prospects in Agwu, S.N. (Ed). (2001) Teaching in Nigeria: A Dynamic Approach. Plateau: Cheston Limited. pp 282-297.

Eluu, P.E. (2011). Evaluation of the implementation of Bible Knowledge Curriculum for Senior Secondary Schools in Ebonyi State. An unpublished Ph.D. Thesis. Ebonyi State University, Abakaliki.

Eluu, P.E. (2013). Refocusing religious education for national development. ANSU Journal of Educational Research. 1 (1). pp 228-235

Ezeh, M.E. \& Okonkwo, U.U. (2011). Christian evangelization in the social fabrics of Igbo people: A reappraisal. ANSU Journal of Integrated Knowledge. 1(1). pp 1-10.

Federal Ministry of Education (1985). National Curriculum for Senior Secondary Schools.Vol. 7: Religious Studies. Lagos: NERDC Press.

Federal Republic of Nigeria (2004). National Policy on Education. Lagos: NERDC Press

Gesinde, A.M. (2000). Motivation. In Omidegy, Z.A.A (Editor) fundamental of guidance and counseling. Ibadan: Kanead Publication

Gotan, S. (2005). Attitude of secondary school students towards the study of CRS. Lagos: Adams Publishers.

Grimmett, M. (Ed). (2000). Pedagogies of religious education, Great Wakering: MeCrimmons.

Harmona, O.A. \& Hunye, K.S. (2006). The Role of Christian religious education in peace and national development. Religious Forum Academia Journal 5(1). pp 224-228.

Henry, I. (2001). Approaches to the study religious knowledge. Ibadan: Macmillan.

Hornby, A.S. (2010). Oxford advanced learners' dictionary of contemporary English language, 8th edition. Oxford: Oxford Press.

Horton D. (General ed) (2006). The Portable Seminary. Grand Rapids, Michigan: Bethany House Publishers.

Israel, A. (2011). Current approach to education (interactive learning). Plateau: Meche Publisher

Ivowi, M.O.U. (2002). Educational challenges for the information age. Interdisciplinary Education Journal (INTEJ) 4(1) pp 3-17.

Johnson, P. (2018) Religious Equity in Schools - Protecting Students and Their Civil Rights.www.idra.org/resource-center/religion-equity-in-schools-protecting-studentsand-their-civil-rights/ 
African Journal of Education and Practice

ISSN 2519-0296 (Online)

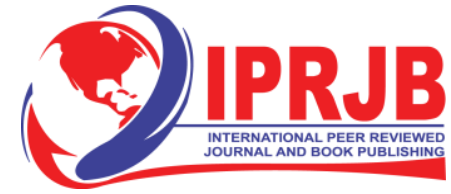

Vol.8, Issue 1, No.1, pp 1-19, 2022

wWw.iprib.org

Joice, B. \& Weil, M. (Eds) (2000). Models of teaching. Boston: Allyn and Bacon.

Long, J.F. (2007). Academic motivation and achievement among urban adolescents. Journal of Urban Education. 42(3). pp 196-222.

Melton, D. \& Serep, T. (2002). Gender differences in academic performance in a Large Public University in Turkey. Journal of Higher Education, 53(1). pp 255-277.

Moor, M.E.M (2000). Sacramental teaching: mediating the holy. In J.M. Lee (Ed), Forging a better religious education in the third millennium 29-50. Birmingham: Religious Education Press.

Morgan, J.H. (2006). Naturally good: a behavioral history of moral development-from Charles Darwin to E.O. Wilson. South Bend Indiana: Cloverdale Books.

Mouton, J. (2001). How to succeed in your Master's and Doctoral studies: A South-African Guide and Resource Book. Hatfield, 0083, Pretoria: Van Schaik Publishers.

Musiban, A.Y. \& Johnson, T.A. (2010). The influence of school sex, location and type on students' academic performance in secondary schools. International Journal of Education 2(2). pp 81-85.

National Council for the Social Studies (NCSS) (2000). National Standards for Social Studies Teachers: Washington: NCSS.

National Council for the Social Studies (NCSS) (2006). Social education. 70 (5). Washington NCSS

National Teachers' Institute (2000). NCE Course book on education. Cycle 2. Kaduna: NTI Press.

Nelson, H. (2002). The principles of teaching methods. London: George G. Harrap\& Co. Ltd.

Nigerian Educational Research Development Council (2013). Universal Basic Education Curriculum (UBE). Revised edition. Lagos: NERDC press.

Njoku, C.N. (2009). Strategies for enhancing Christian religious studies pedagogy in secondary schools in Ebonyi State. Ebonyi State University Journal of Arts and Science Education 1(1). pp 121-127.

Njoku, C.U. (2004). Teaching method for technical and vocational education: A Focus on the New Curriculum. Journal of Arts and Technology Education, (3). pp76-89.

Nsongo, F.L. (2001). Teaching CRE in secondary schools: A handbook for teacher and students' teachers. Nairobi: Catholic University of East Africa.

Nwachukwu, A.O. (2010). Keeping human relationship together-self guide to healthy living. New-York: Universe Inc.

Obanya, P. (2004). Teaching method across the curriculum. London: Collins International Textbooks.

Ocho, L.O. (2005). Issues and concerns in education and life. Plateau: Calvary side publishers. 
African Journal of Education and Practice

ISSN 2519-0296 (Online)

www.iprib.org

Vol.8, Issue 1, No.1, pp 1-19, 2022

Okoro, C.J. (2010). Evaluation of possible constraints to effective religious education in secondary schools: The Nigerian experience. A Thesis submitted to the Department of Education, Graduate Theological Foundation, Mishawaka-Indiana.

Omali, F. (2001). An investigation of the Christian perception of Christian Religious Knowledge as an academic subject in Kastina State. An unpublished M.Ed Thesis. ABU, Zaria.

Omebe, S.E. (2005). Guidance and counseling: a comprehensive approach. Enugu-Nigeria: Cheston Agency Ltd.

UBE (2013) (Revised). Basic education curriculum of Christian religious studies. Lagos: NERDC Press.

Ugwu, A.B.C. (2005). Human learning process. Emene- Plateau: Fred- Ogah publishers.

Ugwu, J.C. (2001). Teacher and pupils' welfare under the Universal Basic Education Program me: A critical analysis. The Nigerian Universal Basic Education Journal. Nsukka: Faculty of Education, University of Nigeria, 1(2). p 174. 